\title{
A new species of Brachiella (Copepoda, Siphonostomatoida, Lernaeopodidae) from Peninsular Malaysia, with relegation of two genera Charopinopsis and Eobrachiella to junior synonyms of Brachiella
}

\author{
Susumu Ohtsuka ${ }^{1, *}$, Wojciech Piasecki ${ }^{2}$, Norshida Ismail ${ }^{3}$, and Ahmad Syazni Kamarudin ${ }^{3}$ \\ ${ }^{1}$ Takehara Station, Setouchi Field Science Centre, Graduate School of Integrated Sciences for Life, Hiroshima University, \\ 5-8-1 Minato-Machi, Takehara, Hiroshima 725-0024, Japan \\ 2 Institute of Marine and Environmental Sciences, University of Szczecin, ul. Mickiewicza 16, 70-383 Szczecin, Poland \\ ${ }^{3}$ School of Animal Science, Faculty of Bioresources and Food Industry, Universiti Sultan Zainal Abidin, 22200 Besut, Terengganu, \\ Malaysia
}

Received 25 March 2020, Accepted 14 May 2020, Published online 28 May 2020

\begin{abstract}
Both sexes of Brachiella malayensis n. sp. are described on the basis of specimens found in the nostrils of narrow-barred Spanish mackerel Scomberomorus commerson (Lacepède) collected off Besut, Malaysia. The female of this species closely resembles those of B. magna Kabata, 1968 and B. cybii Pillai, Prabha et Balaraman, 1982 but is distinguishable mainly by the body size and the proportions of the cephalosome, posterior processes and caudal rami. While examining the male, we noticed a systematic inconsistency in some lernaeopodid genera. The genus Brachiella Cuvier, 1830, represented by its type-species Brachiella thynni Cuvier, 1830, and two monotypic genera Charopinopsis Yamaguti, 1963 and Eobrachiella Ho et Do, 1984, represented by Charopinopsis quaternia (Wilson, 1935) and Eobrachiella elegans (Richiardi, 1880), respectively, share distinct synapomorphies in the embracing (vs. pinching) elongate male maxilliped and the female trunk with a pair of long, cylindrical ventroposterior processes (in addition to a pair of modified caudal rami), both of which are involved in their unique reproductive strategy. The latter two genera are herewith relegated to junior synonyms of Brachiella.
\end{abstract}

Key words: Brachiella, Charopinopsis, Eobrachiella, Lernaeopodidae, Malaysia.

\begin{abstract}
Résumé - Une nouvelle espèce de Brachiella (Copepoda, Siphonostomatoida, Lernaeopodidae) de Malaisie péninsulaire, avec relégation des deux genres Charopinopsis et Eobrachiella en synonymes juniors de Brachiella. Les deux sexes de Brachiella malayensis n. sp. sont décrits sur la base de spécimens trouvés dans les narines du Thazard rayé Scomberomorus commerson (Lacepède) collecté au large de Besut, en Malaisie. La femelle de cette espèce ressemble étroitement à celles de B. magna Kabata, 1968 et B. cybii Pillai, Prabha et Balaraman, 1982, mais se distingue principalement par la taille du corps et les proportions du céphalosome, les processus postérieurs et les rami caudaux. En examinant le mâle, nous avons remarqué une incohérence systématique dans certains genres de Lernaeopodidae. Le genre Brachiella Cuvier, 1830, représenté par son espèce-type Brachiella thynni Cuvier, 1830, et deux genres monotypiques Charopinopsis Yamaguti, 1963 et Eobrachiella Ho et Do, 1984, représentés par Charopinopsis quaternia (Wilson, 1935) et Eobrachiella elegans (Richiardi, 1880), respectivement, partagent des synapomorphies distinctes dans le maxillipède allongé (plutôt que pincé) et le tronc féminin avec une paire de longs processus cylindro-ventro-postérieurs (en plus d'une paire de rami caudaux modifiés), tous deux impliqués dans leur stratégie de reproduction unique. Les deux derniers genres sont ici relégués comme synonymes juniors de Brachiella.
\end{abstract}

\section{Introduction}

Females of the parasitic copepod family Lernaeopodidae are unique in their highly modified bodies, possession of an attachment organ called the bulla joining both maxillae in

*Corresponding author: ohtsuka@hiroshima-u.ac.jp females, and parasitism on gills, mouths, nostrils, eyes, fins, and skins of both marine and freshwater fishes [25, 43, 64]. Dwarf males adhere to bodies of the giant females with their maxillae and maxillipeds [25]. Some lernaeopodids such as Clavella Oken, 1815 and Salmincola Wilson C.B., 1915 have caused negative impacts on marine and freshwater farmed fishes, respectively [20, 38, 44]. 
During our taxonomic survey on parasitic copepods of marine fishes in Malaysia, we found specimens of copepods resembling Brachiella magna Kabata, 1968 but also differing from it. The copepods were collected from the nostrils of narrow-barred Spanish mackerel Scomberomorus commerson (Lacepède). Both sexes of this copepod are described herein. This is the first Malaysian record of the occurrence of a species representing the genus Brachiella.

The largest and most diversified group of the family Lernaeopodidae is the "Brachiella-group" deriving its name from the genus Brachiella Cuvier, 1830. The group is "most highly advanced and apparently very actively speciating, it abounds in species, the large number and the great morphological variety of which add to the difficulties of a sensible taxonomic arrangement" [25]. In fact, the taxonomy of the Brachiella-group has been confusing for decades. It was further complicated by ambiguous definitions and broad interpretation by Wilson [64]. The first comprehensive approach to this large informal "taxon" was by Kabata [25] who not only challenged Wilson's [64] concepts, but also established the genus Neobrachiella Kabata, 1979 to accommodate species differing from the Brachiella type species and sharing some important taxonomic features. These species were previously assigned to Brachiella, Parabrachiella Wilson, C.B., 1915, Probrachiella Wilson C.B., 1915, Epibrachiella Wilson C.B., 1915, Branchiellina Pearse, 1952, Lernaeopoda von Nordmann, 1832 and Isobranchia Heegaard, 1947. The new generic name persisted unchallenged until 2004 when Boxshall and Halsey [6] noticed that the name Parabrachiella should have priority over the name Neobrachiella. As a consequence, many species accommodated in Neobrachiella had to be transferred to Parabrachiella [31, 46]. Kabata [25] not only re-ordered the family Lernaeopodidae, including the Brachiella-group, based on female morphology, but also focused his attention on the morphology of the male. He divided lernaeopodid males, based on their gross morphology, into three types, A, B and C. The most abundant in genera was type A accommodating, among others, the Brachiella-group and freshwater lernaeopodids. Kabata [25] noticed that males of Brachiella and Neobrachiella differ in the structure of their maxillae ("second maxillae") and maxillipeds but he failed to draw conclusions.

Yamaguti [66] and Ho and Do [16] established monotypic genera, Charopinopsis and Eobrachiella, accommodating Charopinus quaternia Wilson, 1935 [65] and Brachiella elegans Richiardi, 1880 [51], respectively. However, close and critical examination of these three genera reveal common morphological characters, which have not hitherto been used for discriminating higher taxa of lernaeopodid copepods. Ho and Do [16] have put forward a hypothesis concerning the reproductive and evolutionary trend of a lernaeopodid lineage. Their hypothesis provides a framework for our analysis on the morphological adaptations of the male and to propose a fundamental change in discriminating lernaeopodid copepods of the Brachiella-group.

\section{Materials and methods}

A host fish head was purchased at a market in Besut, Terengganu, Malaysia $\left(5.8312^{\circ} \mathrm{N}, 102.5619^{\circ} \mathrm{E}\right)$ on 15 October
2019 by the third and fourth authors. Since only the head was available for parasitological examination, the identity of the fish host species was determined using DNA barcoding based on a fragment of the cytochrome c oxidase subunit I (COI) gene in the mitochondrial genome. Approximately $1 \mathrm{~cm}^{2}$ of tissue of the fish species was removed with scissors and preserved in a sterile $1.5 \mathrm{~mL}$ tube containing $95 \%$ ethanol. The total genomic DNA of the fish was isolated using a Favorgen DNA extraction Kit (Favorgen Biotech Corp., Ping-Tung 908, Taiwan). The partial COI gene of mitochondrial DNA was amplified using PCR with the universal primers of COI-Fish2 F (5'-TCGACTAATCATAAAGATATCGGCAC- $\left.3^{\prime}\right)$ and COI-Fish2 R (5'ACTTCAGGGTGACCGAAGAATCAGAA-3') [62]. The PCR was carried out in a $25 \mu \mathrm{L}$ reaction volume containing 18.2 $\mu \mathrm{L}$ sterile distilled water, $2.5 \mu \mathrm{L}$ Taq buffer, $2.0 \mu \mathrm{L}$ dNTP Mix $(2.5 \mathrm{mM}), 0.5 \mu \mathrm{L}$ of each primer $(10 \mu \mathrm{M}), 0.3 \mu \mathrm{L}$ of 5 unit $\mu \mathrm{L}^{-1}$ Taq polymerase (TaKaRa) and $1 \mu \mathrm{L}$ template DNA (50 ng $\mu \mathrm{L}^{-1}$ ) on a thermal cycler PCR machine Veriti 96 Well Thermal Cycler (Applied Biosystems, California, USA). The thermal cycling conditions started with initial denaturation at $95{ }^{\circ} \mathrm{C}$ for $5 \mathrm{~min} ; 35$ cycles including denaturation at $95{ }^{\circ} \mathrm{C}$ for $30 \mathrm{~s}$, annealing at $50{ }^{\circ} \mathrm{C}$ for $30 \mathrm{~s}$ and elongation at $72{ }^{\circ} \mathrm{C}$ for $10 \mathrm{~min}$; followed by a final extension for $10 \mathrm{~min}$ at $72{ }^{\circ} \mathrm{C}$ and then the PCR product was maintained at $4{ }^{\circ} \mathrm{C}$. Sequencing was carried out using a BigDye Terminator v3.1 Cycle Sequencing kit (Applied Biosystems), following the manufacturer's instructions, performed on an ABI Prism 3730XL Genetic Analyzer (Applied Biosystems). Two COI were aligned and edited using the ClustalW multiple sequence alignment program in MEGA 7 [30]. DnaSP software was used to determine the variable sites among the sequence [34]. To discover the origin of the fish species, the sequenced haplotype was queried using the Basic Local Alignment Search Tool (BLAST) against the National Center for Biotechnology (NCBI) nucleotide database and the BOLD identification engine [50]. A top species match was identified with sequence similarity of at least $>90 \%$ to avoid false positives.

The copepods were recovered from the nostrils of the fish host and were preserved in $70 \%$ ethanol for further examination. The copepods were observed in lactophenol on Humes and Gooding's [17] slides, and illustrated with the aid of a drawing tube attached to a microscope (Olympus BX53). The type specimens are deposited at the South China Sea Repository and Reference Center, University Malaysia Terengganu, Malaysia (UMTCrus 1099 and UMTCrus 1100). The terminology used follows Huys and Boxshall [18] and Kabata [25].

\section{Results \\ Host identification}

After removal of low quality sequences at the $5^{\prime}$ and $3^{\prime}$ ends, a 629 bp DNA barcode was obtained in FASTA format. The sequence was deposited in GenBank with the accession number MT423724. The host sequence showed $100 \%$ similarity with sequences of the same species respectively in GenBank (MG220579) and in BOLD identification engine [50], including sequences of the same species collected off the coast of China [5]. This confirms the identification of the host species. 


\section{Taxonomy}

Class: Copepoda Milne Edwards, 1840

Order: Siphonostomatoida Burmeister, 1835

Family: Lernaeopodidae Milne Edwards, 1840

Genus: Brachiella Cuvier, 1830

Synonyms. Charopinus Krøyer, 1863 [48]; Thynnicola Miculicich, 1904 [57]; Charopinopsis Yamaguti, 1963 (new synonymy); Eobrachiella Ho et Do, 1984 (new synonymy).

Diagnosis (amended). Female. Body comprising cylindrical cephalothorax and trunk arranged in line; head slightly enlarged with distinct dorsal shield. Maxillae not medially fused and with bulla attached to host. Maxillipeds substantially displaced in front of maxillae. Trunk cylindrical or more or less dorsoventrally flattened, with pair of dorsoposterior processes (= modified caudal rami) and pair of ventroposterior processes. Gonopores and copulatory pores located ventrolaterally, anterior to caudal rami. Modified caudal rami almost equal to or longer than posterior processes. Antennule 3- or 4-segmented; terminal segment with typical lernaeopodid setation. Antenna heavily sclerotized, with 1- or 2-segmented endopod at angle or parallel to exopod with typical lernaeopodid setation at tip. Mandible with 2 or 3 secondary teeth. Maxillule bilobed, with 2 setae on palp and 3 setae on endite. Maxilliped subchelate; subchela with terminal claw with or without auxiliary spine. Egg sac multiseriate, long.

Male. Body consisting of large cephalothorax with distinct dorsal shield and variably developed trunk. Posterior processes of trunk present or not. Paired gonopores located anterior to caudal rami. Caudal rami unarmed or with rudimentary elements, short or long. Antennule 4-segmented, with typical lernaeopodid setation. Antenna biramous; exopod unilobed, with 2 subterminal elements; endopod 2-segmented, with typical lernaeopodid armament. Mandible and maxillule similar to those of female. Both right and left maxillae linked basally by cuticular tympanum; subchelate, 2-segmented, proximal segment stout, without inner projection at distal corner; distal segment strongly curved inward. Maxilliped embracing (not pinching), elongate, and slender, 2-segmented; corpus with 3 denticulate processes, middle of which bearing element; subchela smoothly curved inward, with denticulate process subterminally and 1 spine or process and 1 small element terminally. Male attached to caudal ramus of female.

Type. Brachiella thynni Cuvier, 1830 [11]

Other species. Brachiella elegans Richiardi, 1880; Brachiella quaternia Wilson, 1935; Brachiella seriolae Yamaguti et Yamasu, 1960; Brachiella magna Kabata, 1968; Brachiella cybii Pillai, Prabha et Balaraman, 1982. (Note that the paper nominally listed as 1977 was published in 1982.)

Remarks. Historically, the taxonomy of Lernaeopodidae was based on female morphology. Also, Wilson [64] depended heavily on female morphology without noticing differences between males of Brachiella and other related genera. Kabata [25] pointed out that the genus Brachiella had accommodated miscellaneous species, and that only the type species $B$. thynni and $B$. magna could be adequately assigned to it. This statement was later repeated by Pillai [48]. Boxshall and Halsey [6] listed lernaeopodid genera with respective number of species. However, they mentioned " 2 " species of Brachiella, without listing the actual species names. In addition, Pillai et al. [49] suggested that B. elegans, B. seriolae and B. gracilis Wilson, 1908 [63] should be re-examined to clearly distinguish Brachiella from other lernaeopodid genera. The study is intended to follow suggestions of some of our predecessors.

Within the last 25 years, many species of the Brachiellagroup have been re-examined and their generic identity confirmed or changed. One of the major obstacles in the classification is the lack of male descriptions in many species.

We decided to include Brachiella cybii in our list of valid species of the newly defined Brachiella, even though the male of $B$. cybii has not been described. This is because the latter species, recovered from the nasal cavity of Acanthocybium solandri (Cuvier), is very similar to B. magna, collected from the gills of $S$. commerson, but it differs in the body proportions (see Table 1).

In addition to the species mentioned above that we have decided to include in the newly defined genus Brachiella, there are also seven hitherto unchallenged Brachiella species that require alternative taxonomic assignment: $B$. sciaenophila (Heller, 1865); B. ovalis van Beneden, 1871; B. fasiculata (Leidy, 1889); B. gracilis; B. lageniformis Szidat, 1955; and B. parva Nuñes-Ruivo, 1957. Brachiella ovalis ("Anchorella ovalis") is Clavellisa emarginata (Krøyer, 1837) but "Anchorella ovalis Krøyer" of van Beneden [59] and "Brachiella ovalis (Krøyer)" of Scott and Scott [53] both represent Parabrachiella bispinosa (von Nordmann, 1832) [25]. Brachiella sciaenophila ("Anchorella sciaenophila") [15] and B. fasiculata ("Anchorella fasiculata") [32] may be moved to Parabrachiella in consideration of the medially fused maxillae of the female. Brachiella neglecta Richiardi, 1880 is a nomen nudum (Article 12, ICZN [19]). "Brachiella (neglecta Richiardi)?" of Brian [7] should be Parabrachiella chevreuxii (Beneden, 1891) [25]. Females of $B$. gracilis have fused maxillae, and its dwarf males cling to the cephalosome of the mate [63]. As such, they clearly represent the "pinching" attachment strategy (vs. embracing strategy of the newly defined Brachiella). Therefore, these should not be included in Brachiella.

The original description of $B$. lageniformis does not provide enough detail about the male [58]. A re-description of both sexes of B. lageniformis provided by Kabata [24] showed that the species has no synapomorphy of Brachiella redefined in our paper. It should be newly transferred to Parabrachiella (see below in Section "Discussion"), because it was not listed in Piasecki et al. [46] nor Lebepe and Dippenaar [31].

Brachiella parva has three pairs of short and thick posterior processes in the trunk [40]. Although the male was also described and illustrated by Nuñes-Ruivo [40], the maxillipeds were not described in detail. Judging from the figure of the whole body (Fig. 2i, p. 98), the male maxilliped seems to be short, unlike that of $B$. thynni.

Another species, that may be erroneously synonymised with B. magna is Epibrachiella magna Song et Chen, 1976 [55]. Its female, however, bears single maxillary processes and three pairs of posterior processes (one pair corresponding to caudal rami) (see Piasecki et al. [46]), and the male does not have long maxillipeds such as seen in B. thynni (see Fig. 8L in [53]). This species is distinctly different from B. magna, and should be moved to the genus Thysanote 
Table 1. A comparison of morphometric and meristic features of females of Brachiella species.

\begin{tabular}{|c|c|c|c|c|c|c|c|}
\hline \multirow[t]{2}{*}{ Parameter } & \multicolumn{7}{|c|}{ Species } \\
\hline & B. malayensis n. sp. & B. magna & B. cybii & B. thynni & B. elegans & B. quaternia & B. seriolae \\
\hline Cephalosome length (CL) [mm] & 3.00 & 6.57 & 7.47 & 6 & 2.78 & 1.67 & 2.75 \\
\hline Cephalosome width [mm] & 1.35 & 1.26 & 2.20 & 1 & 1.22 & 1.17 & 1.40 \\
\hline Trunk length (TL) $[\mathrm{mm}]$ & 3.39 & 7.94 & 12.52 & 6 & 4.78 & 4.22 & 4.83 \\
\hline Trunk width [mm] & 1.09 & 2.07 & 2.00 & 3 & 1.44 & 1.33 & 2.58 \\
\hline Total length $[\mathrm{mm}]$ & 6.39 & 15.0 & 20.0 & 12 & 7.56 & 5.89 & 7.58 \\
\hline TL-CL ratio & 1.13 & 1.33 & 1.68 & 1.00 & 1.72 & 2.53 & 1.76 \\
\hline Dorsoposterior process length (DPL) & 1.48 & 4.20 & 4.51 & 10.00 & 1.00 & 0.78 & 1.80 \\
\hline Ventroposterior process length (VRL) & 1.35 & 4.23 & 3.74 & 7.50 & $3.33 \mathrm{~L}, 4.33 \mathrm{R}$ & 2.89 & 5.20 \\
\hline DPL-TL ratio & 0.44 & 0.53 & 0.23 & 1.38 & 0.21 & 0.18 & 0.37 \\
\hline VRL-TL ratio & 0.44 & 0.53 & 0.19 & 1.04 & $0.70 \mathrm{~L}, 0.91 \mathrm{R}$ & 0.68 & 1.08 \\
\hline Anal tubercle & Present & Present & - & Present & Present & Absent & Present \\
\hline Antennulary segmentation & 4 & 4 & 4 & 4 & 4 & 3 or $4 *$ & 4 \\
\hline No. of elements on antennary endopod tip & 3 & - & - & 3 & 3 & 3 & 2 \\
\hline $\begin{array}{l}\text { Anteriormost seta on maxillulary palp } \\
\text { Maxillae length }\end{array}$ & $\begin{array}{l}\text { Developed } \\
<\text { CL? }\end{array}$ & $\begin{array}{l}\text { Developed } \\
\quad=C L\end{array}$ & - & Developed & Reduced & Reduced & Reduced \\
\hline Patch of denticles on maxillipedal subchela & Absent & $\begin{array}{l}=\mathrm{CL} \\
\text { Present }\end{array}$ & - & Present & $\begin{array}{l}<\mathrm{CL} \\
\text { Present }\end{array}$ & Present & Present \\
\hline Maxillipedal claw with auxiliary spine & No & No & - & No & Yes & Yes & Yes \\
\hline
\end{tabular}

Measurement of B. magna based on Kabata [22]; measurements for B. cybii were based on direct measurement form Pillai et al.'s [49] figure; measurements for B. thynni were based on Wilson [64]; measurements for B. elegans, B. quaterina, and B. seriolae were based on figures or measurement of Ho and Do [16]; " from Kabata [21]; -: no data provided; L = left. $\mathrm{R}=$ right.

Table 2. A comparison of morphometric and meristic features of males of Brachiella species.

\begin{tabular}{|c|c|c|c|c|c|}
\hline \multirow[t]{2}{*}{ Parameter } & \multicolumn{5}{|c|}{ Species } \\
\hline & B. malayensis $\mathrm{n}$. sp. & B. thynni & B. elegans & B. quaternia & B. seriolae \\
\hline Angle between cephalosome and trunk & Right angle & In line & In line & Right angle & In line \\
\hline Cephalosome length (CL) [mm] & 0.56 & 0.89 & 0.60 & $0.57 ?$ & 0.51 \\
\hline Trunk length (TL) $[\mathrm{mm}]$ & 1.03 & 1.14 & 0.67 & Highly reduced & 0.51 \\
\hline Total length [mm] & 1.59 & 2.03 & 1.27 & 0.57 & 1.02 \\
\hline TL-CL ratio & 1.84 & 1.28 & 1.12 & - & 1.00 \\
\hline Ventroposterior processes & Present & Present & Absent? & Absent? & Absent? \\
\hline Dorsoventral processes (caudal rami) & Fusiform & Fusiform & Fusiform & Elongate, cylindrical & Fusiform \\
\hline Antennulary segmentation & 4 & 4 & 4 & $?$ & 4 \\
\hline No. of elements on antennary endopod tip & 3 & 3 & 4 & 4 & 3 \\
\hline Anteriormost seta on maxillulary palp & Developed & Developed & Reduced & Reduced & Reduced \\
\hline Proximal process of maxillipedal corpus & Large & Large & Small & Small & Large \\
\hline Fraction of imMXPs denticulate patch to segment size & $>1 / 2$ & $>1 / 2$ & ca. $1 / 6$ & ca. $1 / 4$ & ca. $1 / 5$ \\
\hline Attachment of male to female ventroposterior processes & $?$ & Yes & Yes & Yes & Yes \\
\hline Reference & Present study & {$[25,54,65]$} & {$[16,65]$} & {$[16,21,66]$,} & [16] \\
\hline
\end{tabular}

The measurements for B. thynni were based on Wilson [64]; measurements for B. elegans, B. quaternia, and B. seriolae were based on figures or measurement of Ho and Do [16]; imMXPs = inner margin of maxilliped subchela.

Krøyer, 1863 as Thysanote magna (Song et Chen, 1976) (new combination).

The genus Charopinopsis was established to accommodate a single species Charopinus quaternius (Wilson, 1935) by Yamaguti [66], in which only the generic diagnosis was provided without any comparison between the newly established genus and its related genus Charopinus. The reason behind Wilson's [65] suggestion about the alleged relation of this copepod with the Charopinus-branch was his false belief about the lack of bulla in $C$. quaternius. This false assumption was sustained by Yamaguti [66]. Later, Kabata [25] recognized the validity of the monotypic genus in consideration of the evolution of the family Lernaeopodidae, and pointed out its phylogenetic position on the Brachiella lineage. Kabata [21] and Ho and Do [16] carefully redescribed Charopinopsis quaternia. Only Ho and Do [16], however, redescribed the male. Kabata [21] proved that the species indeed has a small bulla and listed Brachiella coryphaenae Pearse, 1952 [42] as a junior synonym of $C$. quaternia.

The genus Eobrachiella was erected by Ho and Do [16] to accommodate B. elegans. The main differences between Eobrachiella and Charopinopsis were the presence or absence of an 
anal tubercle in the female and the shape of the caudal rami in the male [16].

However, these three genera share unique maxillipeds of the males, which can be regarded as a distinct synapomorphy. According to Ho and Do [16], the elongate maxillipeds of the males are most likely specialized to embrace the cylindrical ventroposterior process of the females, rather than pinching to avoid detachment from the females parasitic on fast-swimming pelagic fish. The male maxilliped is evidently characterized by three denticulated pads along the inner margin of the corpus, the middle of which has a setule, and an inner, terminal, denticulated pad of the subchela. Such an embracing maxilliped is found in the following six species, including the new species described herein: B. thynni; B. elegans; B. quaternia; $B$. seriolae; B. magna; and B. malayensis n. sp. described below. Brachiella seriolae was described by Yamaguti and Yamasu [67], but later, was relegated to a subspecies of Eobrachiella elegans by Ho and Do [16]. However, we think in consideration of the morphology of both sexes that these are two separate species. In females, the proportion of the cephalosome to the trunk and the fine structure of the antenna are different between these species (Table 1). In males, the general body shape and the morphology of the maxillipeds differ remarkably between these species (Table 2). In addition, these parasitized two different host species of the genus Seriola inhabiting the distant localities: B. elegans in the Atlantic and B. seriolae in the Pacific (Table 1).

Females of these six species share the following features: (1) the female body plan belongs to "Type A" sensu Kabata [25], meaning that the cephalosome and trunk are positioned in line (presumably in a relatively primitive condition); (2) the cephalosome is cylindrical (advanced); (3) pairs of ventro- and dorso-posterior processes of the trunk are well developed, elongate (advanced); (4) the antennae are not prehensile (advanced); (5) the mandible bears primary and secondary teeth (advanced); (6) the maxillae are not medially fused (primitive). Since the six above-mentioned species are well defined by the synapomorphic states of the male maxillipeds and female bodies, we propose herein that Charopinopsis and Eobrachiella are relegated to junior synonyms of Brachiella (new synonymy).

A closely related genus Parabrachiella is now a very specious taxon but unfortunately, in many species only females are known. Since a revision of the genus is beyond the scope of this paper, it should be briefly commented on the basis of the male maxillipeds of the type species as follows: male maxilliped subchelate of pinching type, similar in structure and function to maxilla; corpus unarmed; subchela short, with claw positioned at right angle to shaft; tip of claw fitting depression of medial triangular process of corpus during its closure (cf. Fig. 8, Plate LXIII in [53]). Piasecki et al. [46] transferred B. elegans and $B$. seriolae, both of which were assigned to Eobrachiella by Ho and Do [16], to the genus Parabrachiella without any comment on Eobrachiella.

The homology of ventro- and dorso-posterior processes of the females of Brachiella can be traced in consideration of the counterparts of the males of $B$. thynii and $B$. malayensis n. sp. The dorso-posterior processes represent caudal rami (see Fig. 2C).

\section{Brachiella malayensis Ohtsuka, Piasecki, Norshida et Ahmad-Syazni n. sp. (Figs. 1 and 2)}

\author{
urn:lsid:zoobank.org:act:06D0D2E3-6A51-4628-8B27-
} 3A72C97A45D6

Type-specimens. Holotype, adult female, partly dissected and mounted on 1 slide, body in vial (UMTCrus 1099). Allotype, adult male, partly dissected and mounted on 1 slide, body in vial (UMTCrus 1100). Both specimens were found in the nostrils of Scomberomorus commerson purchased at a fish market in Besut, Terengganu, Malaysia on 15 October 2019.

Type-locality: Off Besut, Terengganu, Malaysia. locality.

Etymology. The new specific name is derived from the type

Description. Female. Body (Figs. 1A and 1B) consisting of cylindrical cephalosome (3.00 $\mathrm{mm}$ in length, $1.35 \mathrm{~mm}$ in maximum width at point of maxillae) and trunk (3.39 $\mathrm{mm}$ in length, $1.09 \mathrm{~mm}$ in maximum width near base of dorsal processes) in line, $6.39 \mathrm{~mm}$ measured from anterior tip of cephalosome to posterior end of trunk. Cephalic shield $(0.80 \mathrm{~mm}$ in length, $0.89 \mathrm{~mm}$ in maximum width) heavily sclerotized, truncate along anterior margin. Maxillae (Fig. 1B, distal parts broken during processing) forming bulla not medially fused, located at ca. anterior 0.47 of total length. Trunk (Fig. 1B) more or less dorsoventrally flattened around posterior ends; paired ventroposterior processes almost equal in length to dorsoposterior processes (= caudal rami). Gonopores ("gp" in Fig. 1C) and copulatory pores ("cp" in Fig. 1C) located ventrolaterally, anterior to base of ventroposterior processes. Mucus remaining on copulatory pores (not illustrated), suggesting post-mating. Anal tubercle (Fig. 1C) located posteriorly, located between caudal rami; anus opening ("a "in Fig. 1C).

Antennule (Fig. 1D) 4-segmented with segments distinctly tapering distally; Second segment with reduced minute seta (whip), third segment unarmed, terminal segment equipped with at least six elements (of unequal size) at tip. Antenna (Fig. 1E) biramous, heavily sclerotized; endopod rudimentary, 1-segmented, positioned at right angle to exopod, having three short elements at tip; exopod lobate, apparently unarmed. Mandible (Fig. 1F) with three primary, three secondary and five basal teeth. Maxillule (Fig. 1G) bilobed, with two short setae on palp and three short setae on endite. Maxilla partly broken during removal from host, lacking terminal parts. Maxilliped (Figs. 1H and 1I) with stout corpus with short inner seta midway; subchela with short element at $1 / 3$ length of inner margin, 1 large terminal claw and 1 minute auxiliary spine.

Male. Body (Figs. 2A and 2B) consisting of semioval cephalosome (cephalic shield: $0.70 \mathrm{~mm}$ in length, $0.49 \mathrm{~mm}$ in maximum width) and longer fusiform trunk $(1.03 \mathrm{~mm}$ in length, $0.42 \mathrm{~mm}$ in maximum width); trunk joined at posteroventral side of cephalosome at right angle, constricted anteriorly, abruptly expanded laterally, and more or less asymmetrically tapering distally in dorsal view (Fig. 2A). Posterior processes of trunk (Fig. 2F) short, just anterior to and covering gonopores. Paired gonopores (Fig. 2F) located anterior to caudal rami. Caudal rami unarmed, shorter than posterior processes. Paired spermatophores (Figs. 2A, 2B, 2F) seen inside posterior part of trunk, oval in ca. $0.15 \mathrm{~mm} \times 0.07 \mathrm{~mm}$ in size. Antennule (Fig. 2G) four-segmented, second segment with 

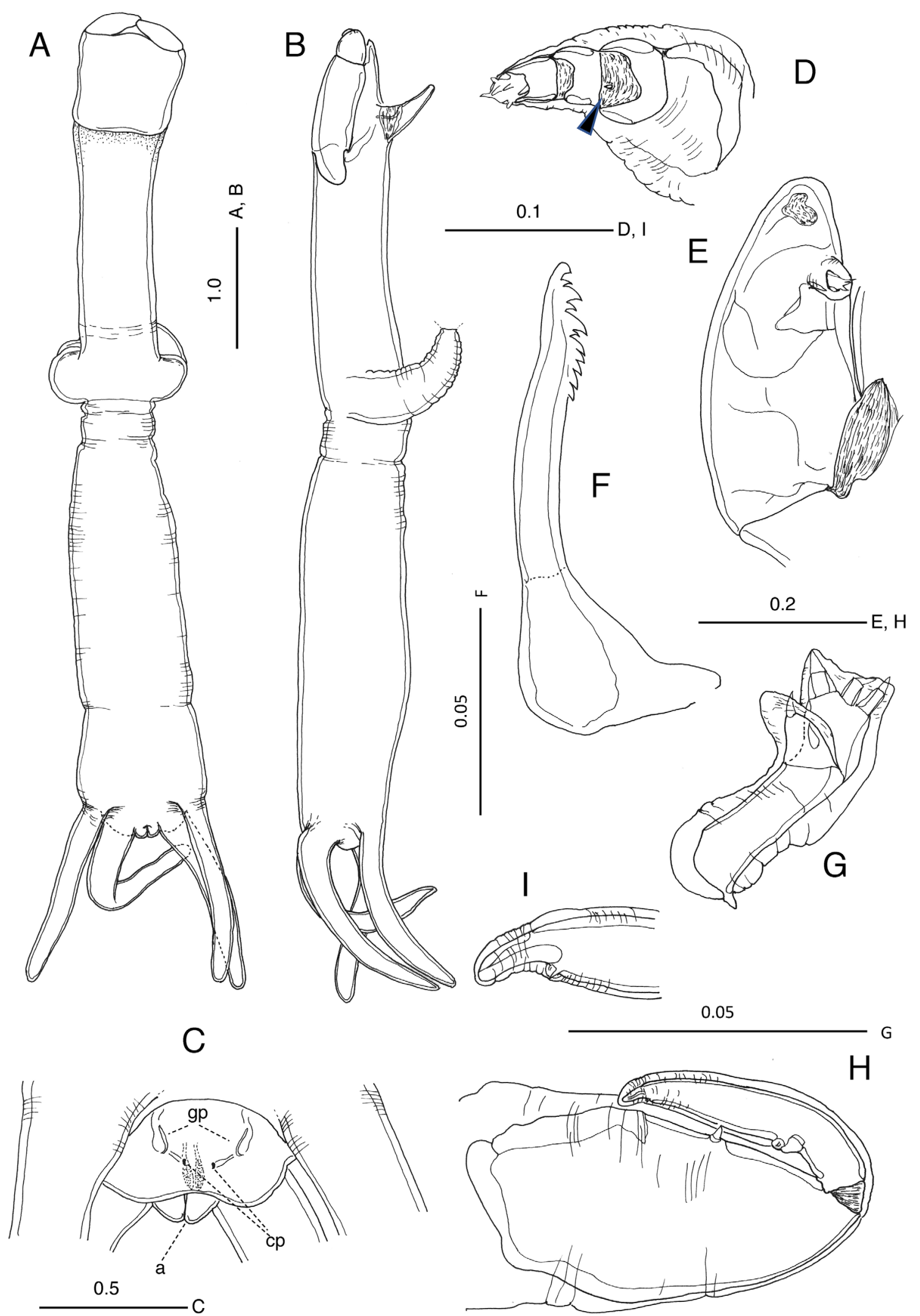

Figure 1. Brachiella malayensis n. sp., female, based on a specimen found from Scomberomorus commerson collected off Besut, Terengganu, Malaysia. (A) Habitus, dorsal view; (B) habitus, lateral view; (C) genital area, ventral view, (a) anus, (gp) gonopore, (cp) copulatory pore; (D) antennule, reduced element arrowed; (E) antenna; (F) mandible; (G) maxillule; (H) maxilliped; (I) tip of maxilliped. Scales in $\mathrm{mm}$. 

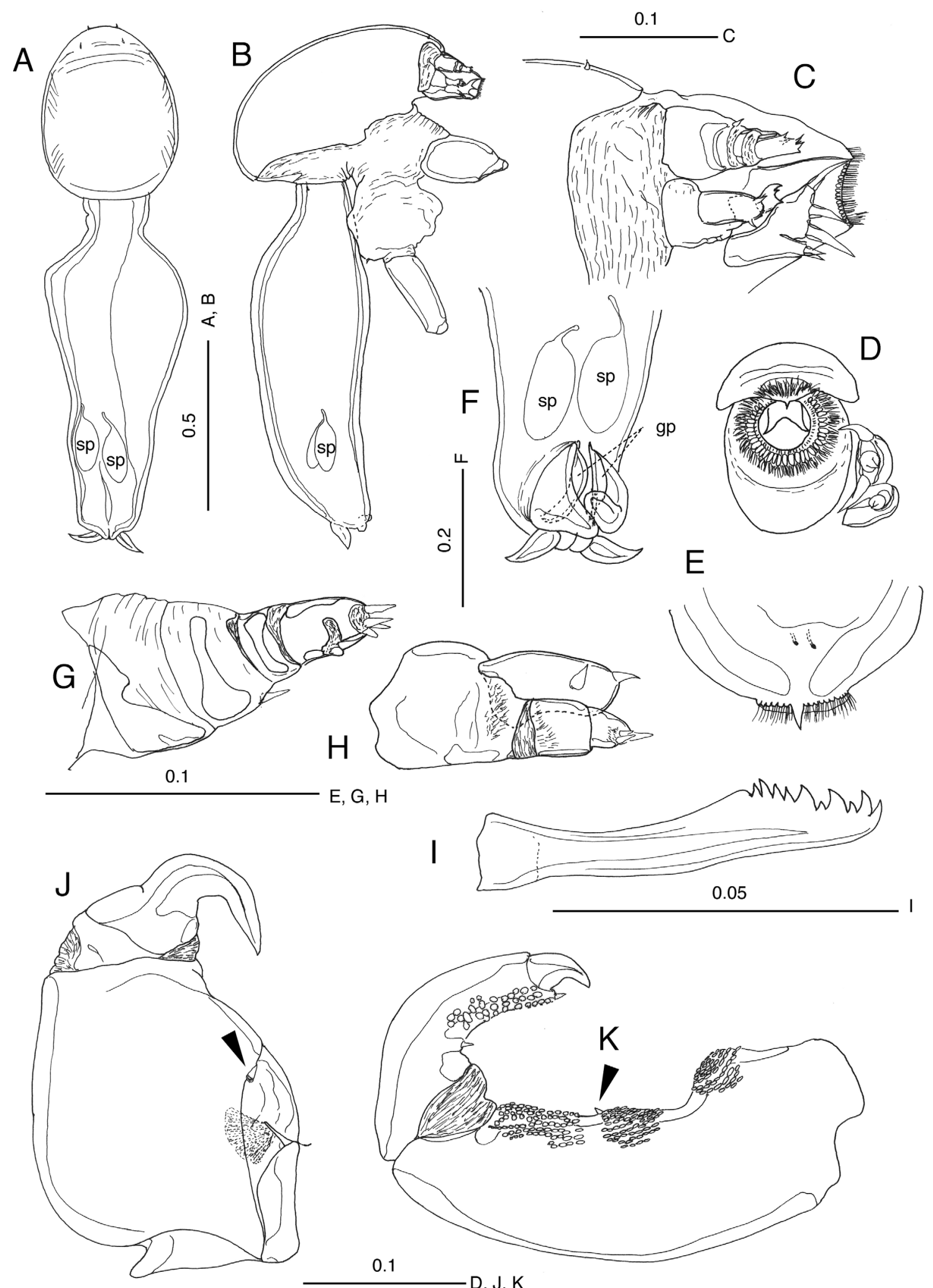

$E, G, H$
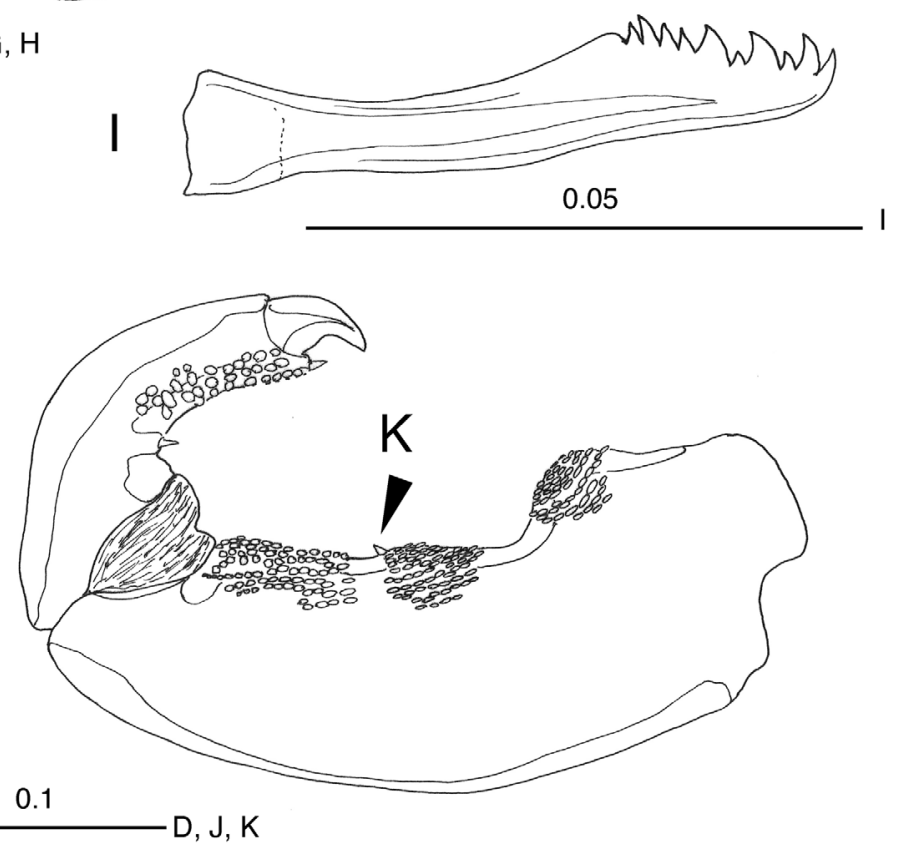

Figure 2. Brachiella malayensis n. sp., male, based on a specimen found from Scomberomorus commerson collected off Besut, Terengganu, Malaysia. (A) Habitus, dorsal view; (B) habitus, lateral view; (C) mouth area, lateral view; (D) oral cone and maxillule, ventral view; (E) labrum, ventral view; (F) genital area, ventral view; (G) antennule; (H) antenna; (I) mandible, (J) maxilla, short element arrowed; (K) maxilliped, short element arrowed. Scales in $\mathrm{mm}$. 
short element (whip) anteriorly, fourth segment having six elements at tip. Antenna (Fig. 2H) biramous; exopod lobate, slightly shorter than endopod, with one subterminal and one terminal element; exopod two-segmented, proximal segment with patch of fine spinules, distal segment having three unequal elements at tip. Mandible (Fig. 2I) with three primary, two secondary and five basal teeth. Oral cone (Figs. 2C, 2D, 2E) situated anteriorly; mouth fringed by membrane enforced with fine setules. Maxillule (Figs. 2C and 2D) bilobed, endite with two short setae terminally; palp with three short and thick setae terminally. Both right and left maxillae linked basally by cuticular tympanum (Fig. 2J); subchelate, two-segmented, proximal segment stout, distal segment with sharp claw strongly curved inward. Maxilliped (Fig. 2K) subchelate, elongate and slender, two-segmented; corpus with three medial denticulate pads, middle of which bearing element; subchela smoothly curved inward, with denticulate pad distomedially and one claw and one small auxiliary spine terminally.

Remarks. Brachiella malayensis n. sp. closely resembles B. magna from Australia and B. cybii from India. These two known species were described only based on a single female. Brachiella magna was found on the gills of S. commerson in Australian waters [22]. Later, Pillai et al. [49] described B. cybii, found in the nasal cavity of $A$. solandri collected off Trivandrum, India.

Brachiella malayensis n. sp. can be distinguished from B. magna in: (1) body length (6.4 mm vs. $15 \mathrm{~mm})$; (2) different proportions of the cephalosome, trunk, posterior processes and caudal rami (see Table 1); (3) the shape of dorsalmost tooth of the mandibular cutting edge (small vs. large); (4) the number of elements of the maxillulary endite (2 vs. 1); (5) lengths of setae on the maxillary palp (short vs. long); (6) group of denticles near the maxillipedal axilla (absent vs. present). Brachiella cybii was very briefly described on the basis of the habitus only by Pillai et al. [49]. However, B. malayensis n. sp. can be differentiated from it by the body size $(6.4 \mathrm{~mm}$ vs. $20 \mathrm{~mm})$ and different body proportions (Table 1 ).

The discovery of the male of the new species reminded us of similarities of males among the type species of Brachiella, B. thynii, and two other lernaeopodid genera Charopinopsis and Eobrachiella. The latter genera are synonymized with Brachiella in the present study. In fact, the male of B. malayensis $\mathrm{n}$. sp. is very similar to those of B. thynni and B. elegans in having a long trunk, but is differentiated by the trunk longer than the cephalothorax (Table 2). The male is also distinguished in the shape of the maxillule, maxilla, and maxilliped from these two congeners (Table 2).

\section{Discussion}

The family Lernaeopodidae has accommodated 46 genera and over 265 species to date, while 20 genera are monotypic [6]. According to Boxshall and Halsey [6], the taxonomy of this family "remains in urgent need of revision". Although Wilson [64], Kabata [21-23, 25, 26], Kabata and Bowman [27], Castro Romero and Baeza Kuroki [9], and Piasecki et al. [46] intensively reviewed the taxonomy of the family, diagnoses of some genera are still ambiguous. This confusion is mainly due to profound modification in the body plan and superficial similarity of appendages, which sometimes makes the phylogenetic relationships obscure [25]. Kabata's [25] vision of the evolutionary trends and phylogenetic relationships among lernaeopodids is suggestive as a landmark for re-definitions of these problematic taxa.

Brachiella can be well defined by the general body plans and long caudal rami of the females and the cephalic appendages of both sexes, especially the distinct synapomorphic state of the male maxillipeds, whereas it exhibits variability in morphology of other body parts of both sexes (Tables 1 and 2). In females, length ratios of cephalothorax to trunk, degrees of trunk expansion, and relative lengths of posterior processes to caudal rami are variable (Table 1). In males, the development of the trunk is highly variable (Table 2). Kabata [25] mentioned that the cephalosome, bulla, and trunk of lernaeopodid females are involved in feeding, attachment, and reproduction, respectively. The cephalosome and trunk of the males are also related to feeding and attachment to the mates and to reproduction, respectively. Therefore, it is likely that such interspecific variation depends on their own reproductive and adaptive strategies on different hosts.

The majority of the species related to the Brachiella-branch have been included in the genus Parabrachiella. Those with maxillary processes were relegated to Thysanote [45]. Only some of them were described based on both sexes. Therefore, the genus Parabrachiella constitutes a potential source of Brachiella species (as presently defined), after their males are discovered and properly described. Piasecki et al. [46] provided a checklist of valid species of Parabrachiella covering a total of 67 species. After 10 years, the list should be updated taking into consideration additional publications [14, 16, 31, 37, 48].

Recently, intraspecific variation of Parabrachiella platensis Montes, Castro-Romero et Martorelli, 2017 was found between specimens collected from nostrils and fins of Mugil liza Valenciennes. The species identification was confirmed by DNA barcoding using mt-DNA COI (similarity 99.8\%) [37]. Minor morphological differences between these specimens were found especially in females: trunk length, shapes of cephalosome, anal slit, posterior truncal processes, labium and maxilla, and armature and elements of antennule, maxillule, and maxilliped [37]. On the other hand, B. magna and B. malayensis n. sp. found from the gills and nostrils of the same host $S$. commerson, respectively, also had a few differences as in the abovementioned remarks. Thus, in the future, a comparison of the DNA sequences of B. malayensis $\mathrm{n}$. sp. and B. magna might be useful to elucidate the validity of species if such variation also occurs between these two species. Although the distal tips (around the bulla) of the maxillae of $B$. malayensis $n$. sp. were accidentally lost during the handling procedure, if the bulla are located at the anteriormost part of the broken right maxilla (left shorter), such short maxillae seem to be adaptive in the narrower habitat, the nostril. The discovery of males of B. magna and B. cybii may confirm the present conclusion.

As Ho and Do [16] have precisely pointed out, males of Brachiella (as Eobrachiella) have an elongate maxilliped which suits embracing the cylindrical caudal ramus rather than pinching, implying avoidance of detachment from the mates on fastswimming pelagic fish. In fact, hosts of Brachiella belong to Carangidae, Coryphaenidae, Peristediidae, Pomatomidae, 
Table 3. A comparison of Brachiella species in terms of their locality, host, and attachment site.

\begin{tabular}{|c|c|c|c|c|c|}
\hline Species & Locality & Host & Family & Attachment site & Reference \\
\hline Brachiella malayensis $\mathrm{n} . \mathrm{sp}$. & Terengganu, Malaysia & $\begin{array}{l}\text { Scomberomorus commerson } \\
\text { (Lacepède, 1800) }\end{array}$ & Scombridae & Nostrils & $\overline{\text { Present study }}$ \\
\hline $\begin{array}{l}\text { Brachiella magna Kabata, } \\
\quad 1968\end{array}$ & Queensland, Australia & $\begin{array}{l}\text { Scomberomorus commerson } \\
\quad \text { (Lacepède, 1800) }\end{array}$ & Scombridae & Gills & [22] \\
\hline $\begin{array}{l}\text { Brachiella cybii Pillai, Prabha } \\
\text { et Balaraman, } 1982\end{array}$ & Trivandrum, India & $\begin{array}{l}\text { Acanthocybium solandri } \\
\quad(\text { Cuvier, 1832) }\end{array}$ & Scombridae & Nostrils & [49] \\
\hline \multirow[t]{11}{*}{$\begin{array}{l}\text { Brachiella thynni Cuvier, } \\
\quad 1830\end{array}$} & - & $\begin{array}{l}\text { [A tuna, as suggested by the } \\
\text { specific epithet] }\end{array}$ & Scombridae & Gills & [11] \\
\hline & - & $\begin{array}{c}\text { "Scomber thynnus" = Thunnus } \\
\text { thynnus (Linnaeus, 1758) }\end{array}$ & Scombridae & Gills & {$[61]$} \\
\hline & - & "Thon" & Scombridae & Gills & [36] \\
\hline & $\begin{array}{l}\text { Axelhulen, } \\
\text { Denmark }\end{array}$ & $\begin{array}{l}\text { "Albecorer" = Thunnus } \\
\text { alalunga? }\end{array}$ & Scombridae & - & {$[56]$} \\
\hline & & $\begin{array}{l}\text { "Baracottaer, Barracuder" = } \\
\text { barracuda? }\end{array}$ & Sphyraenidae & & \\
\hline & Trieste, Italy & $\begin{array}{l}\text { "Thynnusagtige Makrelfisk" = } \\
\text { tuna-like mackerel fish }\end{array}$ & Scombridae & - & [56] \\
\hline & Coast of Belgium & Sciaena umbra Linnaeus, 1758 & & Gills & [59] \\
\hline & Plymouth, England & $\begin{array}{l}\text { "Thynnus thynnus" = Thunnus } \\
\text { thynnus (Linnaeus, 1758) }\end{array}$ & Scombridae & Pectoral fin & [2] \\
\hline & Mediterranean & $\begin{array}{c}\text { "Thynnus vulgaris" = Thunnus } \\
\text { thynnus (Linnaeus, 1758) }\end{array}$ & Scombridae & Gills & [7] \\
\hline & Plymouth, England & $\begin{array}{c}\text { "Thynnus thynnus" = Thunnus } \\
\text { thynnus (Linnaeus, 1758) }\end{array}$ & Scombridae & & [3] \\
\hline & & $\begin{array}{l}\text { "Sciaena aquilla" = } \\
\text { Argyrosomus regius (Asso, } \\
\text { 1801) }\end{array}$ & Sciaenidae & & \\
\hline \multirow[t]{17}{*}{ As "Thynnicola Ziegleri” } & Bakar, Croatia & $\begin{array}{c}\text { "Thynnus thynnus" = Thunnus } \\
\text { thynnus (Linnaeus, 1758) }\end{array}$ & Scombridae & Pectoral fin & [35] \\
\hline & $\begin{array}{l}\text { Polperro, Cornwall, } \\
\text { England }\end{array}$ & $\begin{array}{l}\text { "Thynnus thynnus" }=\text { Thunnus } \\
\text { thynnus (Linnaeus, 1758) }\end{array}$ & Scombridae & - & [39] \\
\hline & - & $\begin{array}{c}\text { "Orcynus thynnus" = Thunnus } \\
\text { thynnus (Linnaeus, 1758) }\end{array}$ & Scombridae & Gills & [53] \\
\hline & Cornwall, England & "tunny fish" & Scombridae & Gills & [64] \\
\hline & Bakar, Croatia & $\begin{array}{c}\text { "Thynnus thynnus" = Thunnus } \\
\text { thynnus (Linnaeus, 1758) }\end{array}$ & Scombridae & Gills & {$[64]$} \\
\hline & Ceylon (Sri Lanka) & & & & [29] \\
\hline & Gulf of Mexico & $\begin{array}{l}\text { Pomatomus saltatrix } \\
\quad \text { (Linnaeus, 1766) }\end{array}$ & Pomatomidae & Axil of pectoral fin & [4] \\
\hline & Off Owase, Japan & $\begin{array}{l}\text { Acanthocybium solandri } \\
\quad \text { (Cuvier, 1832) }\end{array}$ & Scombridae & Around fins & [54] \\
\hline & Hawaii & $\begin{array}{l}\text { Acanthocybium solandri } \\
\quad \text { (Cuvier, 1832) }\end{array}$ & Scombridae & External surface & [33] \\
\hline & British waters? & - & - & - & [25] \\
\hline & $\begin{array}{l}\text { Kerala, India [other } \\
\text { localities and }\end{array}$ & $\begin{array}{l}\text { Thunnus thynnus (Linnaeus, } \\
\text { 1758) }\end{array}$ & Scombridae & - & [48] \\
\hline & $\begin{array}{l}\text { host names were probably } \\
\text { cited after other authors, } \\
\text { based on all }\end{array}$ & $\begin{array}{c}\text { "Thunnus macropterus" = } \\
\text { Thunnus albacares } \\
\text { (Bonnaterre, 1788) }\end{array}$ & Scombridae & & \\
\hline & available records] & $\begin{array}{l}\text { Acanthocybium solandri } \\
\quad \text { (Cuvier, 1832) }\end{array}$ & Scombridae & & \\
\hline & & $\begin{array}{l}\text { Chirocentrus dorab } \\
\text { (Forsskål, 1775) }\end{array}$ & Chirocentridae & & \\
\hline & & $\begin{array}{l}\text { "Indocybium lineolatum" = } \\
\text { Scomberomorus lineolatus } \\
(\text { Cuvier, 1829) }\end{array}$ & Scombridae & & \\
\hline & & $\begin{array}{c}\text { "Orcynus thynnus" = Thunnus } \\
\text { thynnus (Linnaeus, 1758) }\end{array}$ & Scombridae & & \\
\hline & & $\begin{array}{l}\text { Pomatomus saltatrix } \\
\quad \text { (Linnaeus, 1766) }\end{array}$ & Pomatomidae & & \\
\hline
\end{tabular}


Table 3. (Continued)

\begin{tabular}{|c|c|c|c|c|c|}
\hline Species & Locality & Host & Family & $\begin{array}{l}\text { Attachment } \\
\text { site }\end{array}$ & Reference \\
\hline & & $\begin{array}{l}\text { "Sciaena aquilla" = } \\
\text { Argyrosomus regius } \\
(\text { Asso, 1801) }\end{array}$ & Sciaenidae & & \\
\hline & & Sciaena umbra Linnaeus, 1758 & Sciaenidae & & \\
\hline & & $\begin{array}{l}\text { "Sciaena rubra" = Sargocentron } \\
\text { rubrum (Forsskål, 1775) }\end{array}$ & Sciaenidae & & \\
\hline & & $\begin{array}{l}\text { "Scomberomorus cavalla" = } \\
\text { Scomberomorus maculatus } \\
\text { (Mitchill, 1815) }\end{array}$ & Scombridae & & \\
\hline & Yeosu, Korea & $\begin{array}{l}\text { Thunnus alalunga } \\
\quad \text { (Bonnaterre, 1788) }\end{array}$ & Scombridae & Body surface & [60] \\
\hline $\begin{array}{l}\text { Brachiella elegans } \\
\quad \text { Richiardi, } 1880\end{array}$ & Italy & $\begin{array}{c}\text { "Lichia glauca" }=\text { Trachinotus } \\
\text { ovatus }(\text { Linnaeus, 1758) }\end{array}$ & Carangidae & Branchial arches & {$[51]$} \\
\hline \multirow[t]{2}{*}{$\begin{array}{l}\text { "Brachiella sp. } \\
\quad \text { (elegans Rich.?)" }\end{array}$} & $\begin{array}{l}\text { Portoferraio, } \\
\text { Tyrrhenian Sea }\end{array}$ & Lichia amia (Linnaeus, 1758) & Carangidae & Gill cavity & [8] \\
\hline & $\begin{array}{l}\text { Woods Hole, USA, } \\
\text { Atlantic }\end{array}$ & $\begin{array}{l}\text { Seriola lalandi } \\
\quad \text { Valenciennes, } 1833\end{array}$ & Carangidae & Gill cavity & [64] \\
\hline $\begin{array}{l}\text { "Eobrachiella elegans" } \\
\text { ([64] specimens) }\end{array}$ & $\begin{array}{l}\text { Woods Hole, USA, } \\
\text { Atlantic }\end{array}$ & $\begin{array}{l}\text { Seriola lalandi Valenciennes, } \\
\quad 1833\end{array}$ & Carangidae & Gill cavity & [16] \\
\hline \multirow[t]{2}{*}{$\begin{array}{l}\text { "Charopinus quaternius } \\
\text { Wilson, 1935" }\end{array}$} & $\begin{array}{l}\text { Dry Tortugas, } \\
\text { Gulf of Mexico }\end{array}$ & $\begin{array}{l}\text { Peristedion gracile Goode } \\
\text { et Bean, } 1896\end{array}$ & Peristediidae & Gills & [65] \\
\hline & & $\begin{array}{l}\text { Coryphaena hippurus } \\
\text { Linnaeus, } 1758\end{array}$ & Coryphaenidae & Gills & \\
\hline $\begin{array}{l}\text { As "Brachiella coryphaenae } \\
\text { Pearse, 1952" }\end{array}$ & Gulf of Mexico & $\begin{array}{l}\text { Coryphaena hippurus } \\
\text { Linnaeus, } 1758\end{array}$ & Coryphaenidae & Gills and opercula & {$[42]$} \\
\hline "Charopinus quaternius" & Grand Isle, IL, USA & $\begin{array}{l}\text { "Scomberomorus cavalla" = } \\
\text { Scomberomorus maculatus } \\
\text { (Mitchill, 1815) }\end{array}$ & Scombridae & - & [10] \\
\hline As "Brachiella coryphaenae" & Vizhington, India & $\begin{array}{l}\text { Coryphaena hippurus } \\
\text { Linnaeus, } 1758\end{array}$ & Coryphaenidae & $\begin{array}{c}\text { Gill } \\
\text { filaments }\end{array}$ & {$[47]$} \\
\hline "Charopinopsis quaternia" & - & - (In reference to [65] records) & - & - & {$[66]$} \\
\hline "Charopinopsis quaternia" & - & $\begin{array}{l}\text { - (based on Wilson's [65] } \\
\text { specimens }\end{array}$ & - & - & {$[21]$} \\
\hline "Charopinopsis quaternia" & Oahu, Hawaii & $\begin{array}{l}\text { Coryphaena hippurus } \\
\text { Linnaeus, } 1758\end{array}$ & Coryphaenidae & $\begin{array}{l}\text { Gill } \\
\text { filaments }\end{array}$ & [33] \\
\hline "Charopinopsis quaternia" & Daito Is., Japan & $\begin{array}{l}\text { Coryphaena hippurus } \\
\text { Linnaeus, } 1758\end{array}$ & Coryphaenidae & Gill & [28] \\
\hline "Charopinopsis quaternia" & Key West, Gulf of Mexico & $\begin{array}{l}\text { Coryphaena hippurus } \\
\text { Linnaeus, } 1758\end{array}$ & Coryphaenidae & Gills & [16] \\
\hline $\begin{array}{l}\text { Brachiella quaternia new } \\
\text { comb. }\end{array}$ & & & & & Present study \\
\hline $\begin{array}{l}\text { Brachiella seriolae Yamaguti } \\
\text { et Yamasu, } 1960\end{array}$ & Kojima Bay, Japan & $\begin{array}{l}\text { Seriola quinqueradiata } \\
\quad \text { Temminck et Schlegel, } 1845\end{array}$ & Carangidae & Pectoral fins & {$[67]$} \\
\hline $\begin{array}{l}\text { "Eobrachiella elegans } \\
\text { f. seriolae" }\end{array}$ & Kojima Bay, Japan & $\begin{array}{l}\text { Seriola quinqueradiata } \\
\quad \text { Temminck et Schlegel, } 1845\end{array}$ & Carangidae & Pectoral fins & [16] \\
\hline
\end{tabular}

Fish name validity verified after Fricke et al. [12]; -: no data provided.

Sciaenidae, and Scombridae, and Sphyraenidae which are mostly epipelagic [13] (Table 3). Ho and Do's [16] hypothesis is supported by the present study. In situ sites of the males on the females were illustrated in some references. In $B$. seriolae and $B$. quaternia, a male of each species was illustrated to attach himself to the base of the ventroposterior process in Figures 10F, 13B, C and 14A, B of Ho and Do [16], respectively. On the other hand, a male adhered to the terminal portion of the ventroposterior process of a female of B. thynni (see [54]). Since paired copulatory pores are located between the ventroposterior processes, the males seem to prefer attachment to the ventroposterior processes rather than the dorsoposterior ones. Moreover, these different positions of the males on the female ventroposterior processes imply that they are capable of moving freely along the processes. The present study has focused more attention on the reproductive organs and behavior of lernaeopodids to improve understanding of the taxonomy and phylogeny of the family. In fact, free-living calanoid copepods exhibit highly variable configurations in the female reproductive systems (e.g., Barthélémy et al. [1]; Ohtsuka and Huys [41]), which was a key innovation to reconsider the phylogeny of the order. 
Acknowledgements. We would like to express our sincere thanks to Drs. Khamsah Suryati Mohd and Connie Fay Komilus for their encouragement throughout our survey in Malaysia. This study was supported financially by grant-in-aids (KAKENHI, No. 19H03032, Bilateral Partnership Program, No. JPJSBP120209924, both awarded to SO) provided by the Japan Society of Promotion of Science and FRGS grant (FRGS/1/2018/WAB13/UNISZA/02/1) by the Ministry of Education Malaysia awarded to Norshida Ismail. We are grateful to Dr. Christan Capapé of the Université de Montpellier, UM1, for proofreading the French abstract.

\section{Conflict of interest}

The authors declare that they do not have any conflict of interest.

\section{References}

1. Barthélémy R-M, Cuoc C, Defaye D, Brunet M, Mazza J. 1998. Female genital structures in several families of Centropagoidea (Copepoda: Calanoida). Philosophical Transactions of the Royal Society London. Series B: Biological Sciences, 353, 721-736.

2. Bassett-Smith PW. 1896. A list of the parasitic Copepoda of fish obtained at Plymouth. Journal of the Marine Biological Association of the United Kingdom, 4(2), 155-163.

3. Bassett-Smith PW. 1899. A systematic description of parasitic Copepoda found on fishes, with an enumeration of the known species. Proceedings of the General Meetings for Scientific Business of the Zoological Society of London, 67(2), 438-507.

4. Bere R. 1936. Parasitic copepods from Gulf of Mexico fish. American Midland Naturalist, 17(3), 577-625.

5. Bingpeng X, Heshan L, Zhilan Z, Chunguang W, Yanguo W, Jianjun W. 2018. DNA barcoding for identification of fish species in the Taiwan Strait. PLoS One, 13(6), e0198109.

6. Boxshall GA, Halsey SH. 2004. An introduction to copepod diversity. Ray Society: London. p. 966.

7. Brian A. 1898. Catalogo di copepodi parassiti dei pesci della Liguria. Atti della Società Ligustica di Scienze Naturali e Geografiche, 9, 1-31, pls. 1-4.

8. Brian A. 1899. Di alcuni crostacei parassiti dei pesci dell'Isola d'Elba. Atti della Società Ligustica di Scienze Naturali e Geografiche, 10, 1-10.

9. Castro Romero R, Baeza Kuroki H. 1987. Four new species of Neobrachiella (Copepoda: Lernaeopodidae), parasitic on Sciaena genus (Teleostei: Sciaenidae) in the South Pacific. Estudios Oceanológicos, 6, 1-24.

10. Causey D. 1953. Parasitic Copepoda from Grand Isle, Louisiana, vol. 7, Occasional Papers of the Marine Laboratory, Louisiana State University. pp. 1-18.

11. Cuvier G. 1830. Le règne animal distribué d'après son organisation, pour servir de base à l'histoire naturelle des animaux et d'introduction à l'anatomie comparée. Nouvelle édition revue et augmentée. Tome III. Deterville Libraire et Crochard Libraire: Paris.

12. Fricke R, Eschmeyer WN, van der Laan R (Eds.). 2019. Eschmeyer's catalog of fishes: Genera, species, references. California Academy of Sciences: San Francisco, USA. [Accessed on 11 March 2020] http://researcharchive.calacademy.org/research/ichthyology/catalog/fishcatmain.asp

13. Froese R, Pauly D. 2019. FishBase [Version 08/2019]. http:// www.fishbase.org.
14. Gnanamuthu CP. 1951. Brachiella trichiuri n. sp., a copepod parasitic in the mouth cavity of the ribbon fish. Spolia Zeylanica, 26, 13-15.

15. Heller C. 1865. Crustaceen. In: Reise der österreichischen Fregatte Novara um die Erde in den Jahren 1857, 1858, 1859 unter den Befehlen des Commodore B. von Wüllerstorf-Urbair. Zoologischer Theil, zweiter Band, III Abtheilung. KaiserlichKöniglichen Hofund Staatsdruckerei, Wien. 1-280, pls. 1-25

16. Ho JS, Do TR. 1984. Three species of Lernaeopodidae (Copepoda) parasitic on fishes of Japan, with proposition of a new genus and discussion of Charopinopsis Yamaguti, 1963. Publications of the Seto Marine Biology Laboratory, 29, 333358.

17. Humes AG, Gooding RU. 1964. A method for studying the external anatomy of copepods. Crustaceana, 6, 238-240.

18. Huys R, Boxshall GA. 1991. Copepod evolution. Ray Society: London. p. 468.

19. International Commission on Zoological Nomenclature. 1999. International code of zoological nomenclature, 4th edn. International Trust for Zoological Nomenclature, c/o Natural History Museum, London, UK.

20. Johnson SC, Treasurer JW, Bravo S, Nagasawa K, Kabata Z. 2004. A review of the impact of parasitic copepods on marine aquaculture. Zoological Studies, 43, 8-19.

21. Kabata Z. 1964. Revision of the genus Charopinus Krøyer, 1863 (Copepoda: Lernaeopodidae). Videnskabelige fra Dansk Naturhistorisk Forening i København, 127, 85-112.

22. Kabata Z. 1968. Copepoda parasitic on Australian fishes: VIII. Families Lernaeopodidae and Naobranchiidae. Journal of Natural History, 2, 505-523.

23. Kabata Z. 1969. Revision of the genus Salmincola Wilson, 1915 (Copepoda: Lernaeopodidae). Journal of the Fisheries Research Board of Canada, 26, 2987-3041.

24. Kabata Z. 1970. Discovery of Brachiella lageniformis (Copepoda: Lernaeopodidae) in the Canadian Pacific and its significance to zoogeography of the genus Merluccius (Pisces: Teleostei). Journal of the Fisheries Board of Canada, 27, 2159-2165.

25. Kabata Z. 1979. Parasitic Copepoda of British fishes. Ray Society: London. p. 468.

26. Kabata Z. 1990. Revision of the genus Clavellopsis Wilson, 1915 (Copepoda: Lernaeopodidae). Canadian Journal of Zoology, 68, 2564-2566.

27. Kabata Z, Bowman TE. 1961. Revision of Tracheliastes grandis Wilson, 1915 (Copepoda, Lernaeopodidae). Crustaceana, 3, 120-126.

28. Kazačenko VN. 1975. Parazitičeskie rakoobraznye (Copepoda) ryb tropičeskoj časti tihogo i indijskogo okeanov. Izvestâ TINRO, 98, 211-217.

29. Kirtisinghe P. 1935. Parasitic copepods of fish from Ceylon. Parasitology, 27, 332-344.

30. Kumar S, Stecher G, Tamura K. 2016. MEGA7: Molecular Evolutionary Genetic Analysis Version 7.0 for bigger datasets. Molecular Biology and Evolution, 33, 1870-1874.

31. Lebepe MC, Dippenaar SM. 2016. Barnard's Brachiella sp., Parabrachiella supplicans (Barnard, 1955) and Eubrachiella sublobulata (Barnard, 1955) (Copepoda: Siphonostomatoida: Lernaeopodidae) deposited in the Iziko South African Museum. Zootaxa, 4061, 51-60.

32. Leidy J. 1888. [Published 1889] A parasite of the red snapper. Proceedings of the Academy of Natural Sciences of Philadelphia, 40, 138-139.

33. Lewis AG. 1967. Copepod crustaceans parasitic on teleost fishes of the Hawaiian Islands. Proceedings of the United States National Museum, 121(3574), 1-204. 
34. Librado P, Rozas J. 2009. DnaSP v5: a software for comprehensive analysis of DNA polymorphism data. Bioinformatics, 25, 1451-1452.

35. Miculicich M. 1904. Ein neuer Lernaeopodidae. Zoologischer Anzeiger, 28, 47-52.

36. Milne Edwards M. 1840. Histoire naturelle des crustacés, comprenant l'anatomie, la physiologie et la classification de ces animaux. Tome troisième. Librairie encyclopédique de Roret: Paris.

37. Montes MM, Castro-Romero R, Martorelli SR. 2017. Morphological identification and DNA barcoding of a new species of Parabrachiella (Siphonostomatoida: Lernaeopodidae) with aspects of their intraspecific variation. Acta Tropica, 173, 34-44.

38. Nagasawa K, Umino T, Uyeno D, Ohtsuka S, Koizumi H. 2008. Infection with the parasitic copepod Clavella parva (Lernaeopodidae) in gold-eye rockfish Sebastes thompsoni broodstock in Japan. Fish Pathology, 43, 55-60.

39. Norman CAM, Scott T. 1906. The Crustacea of Devon and Cornwall. William Wesley and Son, London. XV + 232 pp, 24 pls.

40. Nuñes-Ruivo L. 1957. Lernaeopodidae (Copepoda) parasites des Trigles. Revista Portuguesa de Zoologia e Biologia Geral, 1, 89-107.

41. Ohtsuka S, Huys R. 2001. Sexual dimorphism in calanoid copepods: morphology and function. Hydrobiologia, 453(454), 441-466.

42. Pearse AS. 1952. Parasitic Crustacea from the Texas coast. Publications of the Institute of Marine Science, Port Aransas, 2 (2), 5-42.

43. Piasecki W, Avenant-Oldewage A. 2008. Diseases caused by Crustacea, in Fish diseases. Eiras J, Segner H, Wahli T, Kapoor BG, Editors. Science Publishers: Enfield, NH, USA. p. 11151200.

44. Piasecki W, Goodwin AE, Eiras JC, Nowak BF. 2004. Importance of Copepoda in freshwater aquaculture. Zoological Studies, 43, 193-205.

45. Piasecki W, Ohtsuka S, Yoshizaki R. 2008. A new species of Thysanote Krøyer, 1863 (Copepoda: Siphonostomatoida: Lernaeopodidae), a fish parasite from Thailand. Acta Ichthyologica et Piscatoria, 38, 29-35.

46. Piasecki W, Młynarczyk M, Hayward CJ. 2010. Parabrachiella jarai sp. nov. (Crustacea: Copepoda: Siphonostomatoida) parasitic on Sillago sihama (Actinopterygii: Perciformes: Sillaginidae). Experimental Parasitology, 125, 55-62.

47. Pillai NK. 1962. Copepods parasitic on South Indian fishes: families Lernaeopodidae and Naobranchidae. Journal of the Marine Biological Association of India, 4, 58-94.

48. Pillai NK. 1985. The fauna of India. Copepod parasites of marine fishes. Zoological Survey of India: Calcutta, India.

49. Pillai NK, Prabha C, Balaraman K. 1977. [Published 1982] Four species of lernaeopodid copepods new to the fauna of India. Journal of the Marine Biological Association of India, 19, 10-15.

50. Ratnasingham S, Hebert PDN. 2007. BOLD: The Barcode of Life Data System (www.barcodinglife.org). Molecular Ecology Notes, 7(3), 355-364.

51. Richiardi S. 1880. Catalogo sistematico dei Crostacei che vivono sul corpo degli animali acquatici in Italia. In: Catalogo
Generale della Sezione Italiana alla Esposizione Internazionale della Pesca in Berlino, 146-153.

52. Scott T. 1901. Notes on some parasites of fishes. Nineteenth Annual Report of the Fishery Board for Scotland being for the year, 1900(3), 120-153.

53. Scott T, Scott A. 1913. The British parasitic Copepoda. Volume I, Copepoda parasitic on fishes. Ray Society, 95-96, 1-257.

54. Shiino S. 1956. Copepods parasitic on Japanese fishes. 12. Family Lernaeopodidae. Report of the Faculty of Fisheries, Prefectural University of Mie, 2, 269-311.

55. Song D, Chen G. 1976. Some parasitic copepods from marine fishes of China. Acta Zoologica Sinica, 22, 406-424 (In Chinese with English abstract).

56. Steenstrup JJS, Lütken CF. 1861. Bidrag til kundskab om det aabne havs snyltekrebs og lernæer samt om nogle andre nye eller hidtil kun ufuldstændigt kjendte parasitiske copepoder. Kongelige Danske Videnskabernes Selskabs Skrifter, 5te Ræke, naturhistorisk og mathematisk Afdeling, Kjöbenhavn, 5, 341432 , pls. $1-15$.

57. Stenta M. 1904. Thynnicola ziegleri Miculicich = Brachiella thynni Cuv. Zoologischer Anzeiger, 28, 345-347.

58. Szidat L. 1955. La fauna de parasitos de «Merluccius hubbsi » como caracter auxiliar para la solucion de problemas sistematicos y zoogeograficos del genero «Merluccius » L. Comunicaciones del Instituto Nacional de Investigaciones de las Ciencias Naturales y Museo Argentino de Ciencias Naturales « Bernardino Rivadavia ». Ciencias Zoológicas, 3, 1-54.

59. Van Beneden P-J. 1871. Les poissons des côtes de Belgique, leurs parasites et leurs commensaux. Mémoires de l'Académie Royale des Sciences, des Lettres et des Beaux-Arts de Belgique, 38 , i-xx, 1-100, pls. 1-8.

60. Venmathi Maran BA, Soh HY, Hwang UW, Chang CY, Myoung J-G. 2015. First records of parasitic copepods (Crustacea, Siphonostomatoida) from marine fishes in Korea. Tropical Biomedicine, 32, 352-364.

61. von Nordmann A. 1832. Mikrographische Beiträge zur Naturgeschichte der wirbellosen Thiere. Zweites Heft. Mit zehn Kupfertafeln. G. Reimer: Berlin. XVIII, 150, plates I-X.

62. Ward RD, Zemlak TS, Innes BH, Last PR, Hebert PDN. 2005. DNA barcoding Australia's fish species. Philosophical Transactions of the Royal Society of London, B: Biological Sciences, $360,1847-1857$.

63. Wilson CB. 1908. North American parasitic copepods: a list of those found upon the fishes of the Pacific coast, with descriptions of new genera and species. Proceedings of the United States National Museum, 35, 1652, 431-481, pls. 66-83.

64. Wilson CB. 1915. North American parasitic copepods belonging to the Lernaeopodidae, with a revision of the entire family. Proceedings of the United States National Museum, 47, 565726.

65. Wilson CB. 1935. Parasitic copepods from the Dry Tortugas. Carnegie Institution of Washington Publications, 452, 329-347.

66. Yamaguti S. 1963. Parasitic Copepoda and Branchiura of fishes. Interscience Publishers: New York, London, Sydney. p. 1104.

67. Yamaguti S, Yamasu T. 1960. Two new species of copepods parasitic on Japanese fishes. Publications of the Seto Marine Biological Laboratory, 8, 137-140.

Cite this article as: Ohtsuka S, Piasecki W, Ismail N \& Kamarudin AS. 2020. A new species of Brachiella (Copepoda, Siphonostomatoida, Lernaeopodidae) from Peninsular Malaysia, with relegation of two genera Charopinopsis and Eobrachiella to junior synonyms of Brachiella. Parasite 27, 40. 
An international open-access, peer-reviewed, online journal publishing high quality papers on all aspects of human and animal parasitology

Reviews, articles and short notes may be submitted. Fields include, but are not limited to: general, medical and veterinary parasitology; morphology, including ultrastructure; parasite systematics, including entomology, acarology, helminthology and protistology, and molecular analyses; molecular biology and biochemistry; immunology of parasitic diseases; host-parasite relationships; ecology and life history of parasites; epidemiology; therapeutics; new diagnostic tools.

All papers in Parasite are published in English. Manuscripts should have a broad interest and must not have been published or submitted elsewhere. No limit is imposed on the length of manuscripts.

Parasite (open-access) continues Parasite (print and online editions, 1994-2012) and Annales de Parasitologie Humaine et Comparée (1923-1993) and is the official journal of the Société Française de Parasitologie. 